\title{
Radioreceptor Binding Profile of the Atypical Antipsychotic Olanzapine
}

Frank P. Bymaster, M.S., David O. Calligaro, Ph.D., Julie F. Falcone, Richard D. Marsh, Nicholas A. Moore, Ph.D., Nicholas C. Tye, Ph.D., Philip Seeman, M.D., and David T. Wong Ph.D.

The affinities of olanzapine, clozapine, haloperidol, and four potential antipsychotics were compared on binding to the neuronal receptors of a number of neurotransmitters. In both rat tissues and cell lines transfected with human receptors olanzapine had high affinity for dopamine $D_{1}, D_{2}, D_{4}$, serotonin $(5 H T)_{2 A}, 5 H T_{2 C}, 5 H T_{3}, \alpha_{1-}$ adrenergic, histamine $H_{1}$, and five muscarinic receptor subtypes. Olanzapine had lower affinity for $\alpha_{2}$-adrenergic receptors and relatively low affinity for $5 H T_{1}$ subtypes, $G A B A_{A}, \beta$-adrenergic receptors, and benzodiazepine binding sites. The receptor binding affinities for olanzapine was quite similar in tissues from rat and human brain. The binding profile of olanzapine was comparable to the atypical antipsychotic clozapine, while the binding profiles for haloperidol, resperidone, remoxipride, $\operatorname{Org} 5222$, and seroquel were substantially different from that of clozapine. The receptor binding profile of olanzapine is consistent with the antidopaminergic, antiserotonergic, and antimuscarinic activity observed in animal models and predicts atypical antipsychotic activity in man.

[Neuropsychopharmacology 14:87-96, 1996]
KEY WORDS: Olanzapine; Clozapine; Haloperidol; Antipsychotic; Binding profile; Dopamine; Risperidone; Seroquel; Org 5222

Neuroleptics have been used for several decades to treat the positive symptoms of schizophrenia such as delusions and hallucinations (Davis and Casper 1974). However, classical neuroleptics like haloperidol produce movement disorders referred to as extrapyramidal side effects (EPSs) and tardive dyskinesia (Tarsy 1983). Antipsychotics are believed to act via blockade of dopamine $D_{2}$ receptors (Seeman et al. 1976), and the EPSs have been attributed to a high degree of occupation of

From Lilly Research Laboratories, (FPB, DOC, JFF, RDM, DTW), Lilly Corporate Center, Indianapolis, IN; Lilly Research Centre (NAM, NCT), Eli Lilly and Co., Erl Manor, Windlesham, Surrey, UK; and the Pharmacology and Psychiatry Departments (DTW), University of Toronto, Toronto, Ontario, Canada.

Received August 17, 1994, revised November 7, 1994, accepted December 7, 1994.

Address correspondence to Frank P. Bymaster, Drop Code 0510, Lilly Research Laboratories, Lilly Corporate Center, Indianapolis, IN 46285 . dopamine $\mathrm{D}_{2}$ receptors in the striatum of neuroleptictreated schizophrenics (Farde et al. 1989).

Unlike typical antipsychotics, clozapine, a dibenzodiazepine, has been found to be an effective antipsychotic that rarely produces EPSs or tardive dyskinesia (Casey 1989; Claghorn et al. 1987) and thus was termed atypical. Further, clozapine uniquely reduced the negative symptoms as well as the positive symptoms of schizophrenia and was active in a portion of treatment-resistant patients (Kane et al. 1988). Explanations of the atypical nature of clozapine have focusd on its interaction with several neuronal receptors other than dopamine $\mathrm{D}_{2}$, including dopamine $\mathrm{D}_{1}$ (Andersen et al. 1986), dopamine $D_{4}$ (Van Tol et al. 1991), seroto$\operatorname{nin}(5 \mathrm{HT})_{2 \mathrm{~A}}$ (Meltzer et al. 1989), 5HT $2 \mathrm{C}$ (Canton et al. 1990; Roth et al. 1992), and muscarinic subtypes (Miller and Hiley 1974). In addition, clozapine was recently reported to have high affinity for the cloned $5 \mathrm{HT}_{6}$ and $5 \mathrm{HT}_{7}$ receptors (Roth et al. 1994). Although clozapine is an efficacious antipsychotic and may be considered the prototype for atypical antipsychotics, its use has 
Table 1. Experimental Conditions for Radioligand Einding to Subtypes of Dopamine and Serotonin Receptors

\begin{tabular}{|c|c|c|c|c|c|c|}
\hline $\begin{array}{l}\text { Receptor } \\
\text { Subtype }\end{array}$ & $\begin{array}{c}{\left[^{3} \mathrm{H}\right] \text { ligand }} \\
\text { Concentration } \\
\left(K_{\mathrm{d}}, \mathbf{n M}\right)\end{array}$ & $\begin{array}{c}\text { Membrane } \\
\text { Source }\end{array}$ & Buffer & $\begin{array}{c}\text { Incubation } \\
\text { Time (min) } \\
\text { temp }{ }^{\circ} \mathrm{C}\end{array}$ & $\begin{array}{c}\text { Nonspecific } \\
\text { Binding Compound } \\
(\mu \mathrm{M})\end{array}$ & Reference \\
\hline $\begin{array}{l}\text { Dopamine } \\
\mathrm{D}_{1}\end{array}$ & $\begin{array}{r}\mathrm{SCH} 23390 \\
0.2,0.39\end{array}$ & Striatum & Tris $\mathrm{Cl}^{a}$ & 30,22 & $\begin{array}{c}\mathrm{SCH} 23390 \\
0.03\end{array}$ & $\begin{array}{l}\text { Seeman et al. } \\
1979\end{array}$ \\
\hline $\begin{array}{l}\text { Dopamine } \\
\mathrm{D}_{2}\end{array}$ & $\begin{array}{r}\text { Raclopride } \\
0.8,1.26\end{array}$ & Striatum & Tris $\mathrm{Cl}^{a}$ & 30,22 & $\begin{array}{c}\text { Spiperone } \\
0.03\end{array}$ & Hall et al. 1988 \\
\hline $\begin{array}{l}\text { Dopamine } \\
\mathrm{D}_{4}\end{array}$ & $\begin{array}{l}\text { Spiperone } \\
0.25,0.07\end{array}$ & COS-7 cells & Tris $\mathrm{Cl}^{b}$ & 120,22 & $\begin{array}{l}\text { Dopamine } \\
30\end{array}$ & $\begin{array}{l}\text { Seeman and Van } \\
\text { Tol 1993a }\end{array}$ \\
\hline $5 \mathrm{HT}_{1 \mathrm{~A}}$ & $\begin{array}{c}\text { 8-OHDPAT } \\
0.4,2.9\end{array}$ & Rat cortex & Tris $\mathrm{Cl}^{\mathrm{c}}$ & 30,22 & $\begin{array}{l}\text { Spiperone } \\
10\end{array}$ & Wong et al. 1991 \\
\hline $5 \mathrm{HT}_{1 \mathrm{~B}}$ & 5HT $1,2.2$ & Rat $c$ & Tris $\mathrm{Cl}^{c, d}$ & 15,37 & $5 \mathrm{HT} 10$ & Wong et al. 1991 \\
\hline $5 \mathrm{HT}_{1 \mathrm{D}}$ & 5HT $1,4.4$ & Beef striatum & Tris $\mathrm{Cl}^{c, d}$ & 15,37 & 5HT 10 & Wong et al. 1991 \\
\hline $5 \mathrm{HT}_{2 \mathrm{~A}}$ & $\begin{array}{c}\text { Ketanserin } \\
0.4,1.4\end{array}$ & Cortex & Tris $\mathrm{Cl}^{c}$ & 30,37 & $\begin{array}{l}\text { Spiperone } \\
10\end{array}$ & Wong et al. 1991 \\
\hline $5 \mathrm{HT}_{2 \mathrm{C}}$ & Mesulergine 2 & Human cortex & Tris $\mathrm{Cl}^{c, e}$ & 30,37 & Mianserin 10 & Wong et al. 1991 \\
\hline $5 \mathrm{HT}_{2 \mathrm{C}}$ & Mesulergine 2, 1.0 & plexus & & & Mianserin 10 & Wong et al. 1991 \\
\hline $5 \mathrm{HT}_{3}$ & LY278584 1, 0.7 & Rat cortex & Tris $\mathrm{Cl}^{\mathrm{c}}$ & 30,25 & $5 \mathrm{HT} 10$ & Wong et al. 1991 \\
\hline
\end{tabular}

The concentration of Tris $\mathrm{Cl}$ buffer was $50 \mathrm{mM}$ at $\mathrm{pH} 7.4$

a Salts added: $120 \mathrm{mM} \mathrm{NaCl}, 5 \mathrm{mM} \mathrm{KCl}, 2 \mathrm{mM} \mathrm{CaCl}, 1 \mathrm{mM} \mathrm{MgCl}_{2}$.

${ }^{b}$ Salts added: $120 \mathrm{mM} \mathrm{NaCl}, 5 \mathrm{mM} \mathrm{KCl}, 1.5 \mathrm{mM} \mathrm{CaCl}_{2}, 4 \mathrm{mM} \mathrm{MgCl}, 1 \mathrm{mM}$ EDTA

${ }^{c}$ Added $10 \mu \mathrm{M}$ pargyline and $0.1 \mathrm{mg} / \mathrm{ml}$ ascorbic acid.

${ }^{d}$ Added SCH23390 and 8-OHDPAT at $100 \mathrm{nM}$ each as masking agents.

${ }^{e}$ Added ketanserin and 8-OHDPAT at $100 \mathrm{nM}$ each as masking agents.

been curtailed because of occurrence of agranulocytosis in $1 \%$ to $3 \%$ of patients (Krupp and Barnes 1992).

Recently, a series of thienobenzodiazepines have been synthesized (Chakrabarti et al. 1980). One member of the series, olanzapine [LY170053, 2-methyl-4-(4methyl-1-piperazinyl)-10H-thieno[2,3-B][1,5]benzodiazepine], has been shown to have a pharmacological profile in animals similar to that of clozapine (Moore et al. 1992). For example, in an animal model of antipsychotic activity, conditioned avoidance responding, olanzapine had a favorable ratio of potency versus occurrence of catalepsy, a result that may be predictive of a low incidence of EPSs in man (Moore et al. 1992). In addition, like clozapine, olanzapine had potent antiserotonergic activity in vivo as evidenced by the inhibition of 5-hydroxytrytophan-induced head twitches in mice (Moore et al. 1992) and quipazine-induced increases in serum corticosterone in rats (Fuller and Snoddy 1992). Olanzapine had high affinity for cloned $5 \mathrm{HT}_{6}$ receptors as was found with clozapine, but had only moderate affinity for cloned $5 \mathrm{HT}_{7}$ receptors (Roth et al. 1994). Further, as with clozapine, chronic treatment of rats with olanzapine reduced the number of spontaneously active dopamine cells in the ventral tegmental area, but not in the substantia nigra (Stockton and Rasmussen 1996). Moreover, in clinical trials, olanzapine has been shown to have antipsychotic activity and did not produce appreciable EPSs (Beasley et al. 1996). We report here that olanzapine has a binding profile similar to that of clozapine and exhibits high affinity for dopamine $\mathrm{D}_{1}, \mathrm{D}_{2}, \mathrm{D}_{4}, 5 \mathrm{HT}_{2 \mathrm{~A}}, 5 \mathrm{HT}_{2} \mathrm{C}, 5 \mathrm{HT}_{3}$, muscarinic, $\alpha_{1}$-adrenergic, and histamine $\mathrm{H}_{1}$ receptors in rat and human tissue and in cell lines transfected with human receptors. The binding profile of olanzapine was compared to clozapine, haloperidol, and the new potential antipsychotics risperidone (Roose et al. 1988), remoxipride (Lewander et al. 1990), Org 5222 (Siten and Vrijmoed-de Vries 1992) and seroquel (Migler et al. 1993). Portions of these data have been presented in preliminary form (Moore et al. 1993; Wong et al. 1993).

\section{MATERIALS AND METHODS}

For serotonergic and muscarinic receptor binding assays, male Sprague-Dawley rats (Harlan SpragueDawley, Indianapolis, IN) weighing 100-150 g were sacrificed by decapitation, the brains quickly removed and either whole brain was obtained or cerebral cortex and striatum were dissected on ice. Beef brain was removed immediately after slaughter and striatum and choroid plexus were dissected over ice. Membranes were prepared according to previously described methods (Wong et al. 1991). For dopamine $D_{1}, D_{2}$, $\alpha_{1^{-}}, \alpha_{2^{-}}, \beta$-adrenergic, histamine $\mathrm{H}_{1}$, and benzodiazepine receptor binding, the rat brain tissues were obtained from Pel-Freeze Biologicals (Rogers, AR), and membranes were prepared according to appropriate methods as detailed in Tables 1 and 2 .

Hearts were removed from rats, blotted, and homogenized in 50 volumes of $50 \mathrm{mM}$ Tris- $\mathrm{Cl}$ buffer, $\mathrm{pH} 7.4$, for 30 seconds with a polytron. Cardiac membranes were isolated by centrifugation at $50,000 \times \mathrm{g}$ for 10 minutes, resuspension of the pellet in fresh buffer, 
Table 2. Experimental Conditions for Radioligand Binding to Subtypes of Muscarinic and Other Receptors

\begin{tabular}{|c|c|c|c|c|c|c|}
\hline $\begin{array}{l}\text { Receptor } \\
\text { Subtype }\end{array}$ & $\begin{array}{c}{\left[{ }^{3} \mathbf{H}\right] \text { ligand }} \\
\text { Concentration } \\
\left(\mathbf{K}_{\mathrm{d}}, \mathbf{n M}\right)\end{array}$ & $\begin{array}{l}\text { Membrane } \\
\text { Source }\end{array}$ & Buffer & $\begin{array}{c}\text { Incubation } \\
\text { Time } \\
\left.\text { (min temp }{ }^{\circ} \mathrm{C}\right)\end{array}$ & $\begin{array}{c}\text { Nonspecific } \\
\text { Binding } \\
\text { Compound }(\mu \mathrm{M})\end{array}$ & Reference \\
\hline $\begin{array}{l}\text { Muscarinic } \\
\mathrm{m}_{1}\end{array}$ & Pirenzepine 1,3 & Cortex & $\begin{array}{l}\text { Tris Cl } 20 \mathrm{mM} \\
\mathrm{pH} 7.4^{a}\end{array}$ & 60,25 & Atropine 1 & Potter et al. 1988 \\
\hline $\begin{array}{l}\text { Muscarinic } \\
\mathrm{m}_{2}\end{array}$ & NMS $0.24,0.3$ & Rat heart & $\begin{array}{l}\mathrm{NaPi} 50 \mathrm{mM} \\
\text { pH } 7.4^{b}\end{array}$ & 120,25 & Atropine 1 & $\begin{array}{l}\text { Waelbroeck et al. } \\
1990\end{array}$ \\
\hline $\begin{array}{l}\text { Muscarinic } \\
\mathrm{m}_{3}\end{array}$ & NMS $0.24,0.08$ & $\begin{array}{l}\text { Salivary } \\
\text { gland }\end{array}$ & $\begin{array}{c}\mathrm{NaPi} 50 \mathrm{mM} \\
\mathrm{pH} 7.4^{b, c}\end{array}$ & 120,25 & Atropine 1 & $\begin{array}{l}\text { Lazareno et } \\
\text { al. } 1990\end{array}$ \\
\hline $\begin{array}{l}\text { Muscarinic } \\
\mathrm{m}_{4}\end{array}$ & NMS $0.24,0.05$ & Rat striatum & $\begin{array}{l}\mathrm{NaPi} 50 \mathrm{mM} \\
\mathrm{pH} 7.4^{d}\end{array}$ & $\begin{array}{l}120+45 \\
\quad \text { dissociation, } 25\end{array}$ & Atropine 1 & $\begin{array}{l}\text { Waelbroeck et } \\
\text { al. } 1990\end{array}$ \\
\hline $\begin{array}{l}\text { Musarinic } \\
\text { m1 }_{1}\end{array}$ & NMS $0.24,0.06$ & CHO-K1 & $\begin{array}{c}\mathrm{NaPi} 50 \mathrm{mM} \\
\mathrm{pH} 7.4^{b}\end{array}$ & 120,25 & Atropine 1 & Dorje et al. 1991 \\
\hline $\begin{array}{l}\text { Muscarinic } \\
\mathrm{m}_{3}\end{array}$ & NMS $0.24,0.06$ & CHO-K1 & $\begin{array}{l}\mathrm{NaPi} 50 \mathrm{mM} \\
\mathrm{pH} 7.4^{b}\end{array}$ & 120,25 & Atropine 1 & Dorje et al. 1991 \\
\hline $\begin{array}{l}\text { Muscarinic } \\
\mathrm{m}_{4}\end{array}$ & NMS $0.24,0.05$ & CHO-K1 & $\begin{array}{l}\mathrm{NaPi} 50 \mathrm{mM} \\
\text { pH } 7.4^{b}\end{array}$ & 120,25 & Atropine 1 & Dorje et al. 1991 \\
\hline $\begin{array}{l}\text { Muscarinic } \\
\mathrm{m}_{5}\end{array}$ & NMS $0.24,0.22$ & CHO-K1 & $\begin{array}{l}\mathrm{NaPi} 50 \mathrm{mM} \\
\text { pH } 7.4^{b}\end{array}$ & 120,25 & Atropine 1 & Dorje et al. 1991 \\
\hline $\begin{array}{l}\text { Adrenergic } \\
\alpha_{1}\end{array}$ & $\begin{array}{l}\text { Prazosin } \\
0.2,0.05\end{array}$ & Whole brain & $\begin{array}{c}\text { Tris Cl } 50 \mathrm{mM} \\
\mathrm{pH} 7.7\end{array}$ & 30,25 & WB4101 0.1 & $\begin{array}{c}\text { Greengrass and } \\
\text { Bremner } 1979\end{array}$ \\
\hline $\begin{array}{l}\text { Adrenergic } \\
\boldsymbol{\alpha}_{2}\end{array}$ & $\begin{array}{c}\text { Rauwoscine } \\
0.4,0.6\end{array}$ & Whole brain & $\begin{array}{l}\text { Tris Cl } 50 \mathrm{mM} \\
\mathrm{pH} 7.7^{d}\end{array}$ & 15,22 & Mianserin 10 & $\begin{array}{l}\text { Boyajian and } \\
\text { Leslie, } 1987\end{array}$ \\
\hline$\underset{\beta}{\text { Adrenergic }}$ & DHA $0.2,0.16$ & Whole brain & $\begin{array}{c}\text { Tris Cl } 50 \mathrm{mM} \\
\mathrm{pH} 7.7\end{array}$ & 15,23 & (-) Propanolol 1 & $\begin{array}{l}\text { Bylund and } \\
\text { Snyder } 1976\end{array}$ \\
\hline $\begin{array}{l}\text { Histamine } \\
\mathrm{H}_{1}\end{array}$ & $\begin{array}{l}\text { Pyrilamine } 2 \text {, } \\
4.0\end{array}$ & Whole brain & $\begin{array}{l}\mathrm{NaPi} 50 \mathrm{mM} \\
\mathrm{pH} 7.5\end{array}$ & 30,25 & Promethazine 10 & Tran et al. 1978 \\
\hline $\mathrm{GABA}_{\mathrm{A}}$ & $\begin{array}{l}\text { Muscimol 2, } \\
0.84\end{array}$ & Cortex & $\begin{array}{l}\text { Tris Cl } 50 \mathrm{mM} \\
\text { pH } 7.4\end{array}$ & 30,37 & GABA 10 & $\begin{array}{c}\text { Williams and } \\
\text { Risley } 1979\end{array}$ \\
\hline $\begin{array}{l}\text { Benzodi- } \\
\text { azepine }\end{array}$ & $\begin{array}{l}\text { Flunitrazepam } \\
\quad 2,1.85\end{array}$ & Whole brain & $\begin{array}{l}\text { Tris } \mathrm{Cl} 50 \mathrm{mM} \\
\mathrm{pH} 7.4\end{array}$ & 20,37 & Clonazepam 10 & $\begin{array}{l}\text { Braestrup and } \\
\text { Squires } 1977\end{array}$ \\
\hline
\end{tabular}

a Added $1 \mathrm{mM} \mathrm{MnCl}_{2}$.

${ }^{b}$ Added $2 \mathrm{mM} \mathrm{MgCl}$.

${ }^{c}$ Added $100 \mathrm{mM} \mathrm{NaCl}$.

d Salts added: $120 \mathrm{mM} \mathrm{NaCl}, 5 \mathrm{mM} \mathrm{KCl}, 2 \mathrm{mM} \mathrm{CaCl}, 1 \mathrm{mM} \mathrm{MgCl}$.

and centrifugation again. The cardiac membranes were resuspended at $0.5 \mathrm{~g} / 3 \mathrm{ml}$ buffer and frozen at $-70^{\circ} \mathrm{C}$ until used. Submaxillary salivary glands from rats were homogenized in 50 volumes of $50 \mathrm{mM} \mathrm{Na}$ phosphate, pH 7.4, containing $100 \mathrm{mM} \mathrm{NaCl}$, and membranes were isolated by centrifugation at $50,000 \times \mathrm{g}$ for 10 minutes, resuspension of the pellet in fresh buffer, and centrifugation again. Large pieces of tissue were removed from the homogenate by filtering through cheesecloth. Binding in salivary glands was determined in tissue that had not been frozen.

Chinese hamster ovary cell lines (CHO-K1) transfected with muscarinic receptor subtypes (Dorje et al. 1991) were obtained from Dr. Mark Brann at the University of Vermont. The cells were grown in a monolayer at $37^{\circ} \mathrm{C}$ in a humidified atmosphere containing $5 \%$ $\mathrm{CO}_{2}$ and were cultured in Dulbecco's modified Eagle's medium supplemented with $10 \%$ fetal bovine serum (Gibco, Grand Island, NY), 100 units of penicillin G/l, $100 \mu \mathrm{g}$ streptomycin/l, $4 \mathrm{mM}$ L-glutamine and $100 \mu \mathrm{M}$ MEM nonessential amino acids. After growing to about $80 \%$ confluency, the cells were harvested with $0.25 \%$ trypsin in $\mathrm{Ca}^{++}$-free medium, centrifuged, and frozen until used. After vigorous suspension with a polytron, the cells were washed two times with $20 \mathrm{mM}$ Tris- $\mathrm{Cl}$ buffer, $\mathrm{pH} 7.4$, followed by centrifugation. The number of cells/tube were adjusted to bind $5 \%$ to $8 \%$ of the radioligand. For dopamine $\mathrm{D}_{4}$ binding COS-7 cells were transiently transfected with the human $\mathrm{D}_{4}$ receptor, and binding to receptors was determined as described in Seeman and Van Tol (1993a).

Autopsy samples of human frontal cortex and corpus striatum (Analytical Biological Services, Inc., Wilmington, DE) were processed identically to the method for rat brain tissue.

The binding assay methods are summarized in Tables 1 and 2. After incubation for the specified period, the homogenates were filtered through glass filters (Whatman, GF/c or GF/b, Maidstone, England) with vacuum. The filters were washed several times with cold buffer and placed in scintillation vials containing $10 \mathrm{ml}$ of scintillation fluid (Ready Protein ${ }^{+}$, Beckman, Fullerton, CA). Filters were presoaked in either $0.05 \%$ or $0.1 \%$ polyethylenimine for several hours. Radioactivity trapped on the filters was determined by liquid scintillation spectrometry at approximately $40 \%$ efficiency.

The mean $\mathrm{IC}_{50}$ values were generally obtained 
Table 3. The $K_{i}$ Values for Olanzapine, Clozapine, and Other Antipsychotic Compounds for Dopamine Receptor Subtypes

\begin{tabular}{lccc}
\hline & \multicolumn{3}{c}{$\boldsymbol{K}_{\mathbf{i}}(\mathbf{n M})$} \\
\cline { 2 - 4 } Compound & $\mathbf{D}_{\mathbf{1}}$ & $\mathbf{D}_{\mathbf{2}}$ & $\mathbf{D}_{\mathbf{4}}$ \\
\hline Olanzapine & $31 \pm 0.7$ & $11 \pm 2$ & $27 \pm 3$ \\
Clozapine & $85 \pm 0.7$ & $125 \pm 20$ & $9 \pm 1^{b}, 21 \pm 2^{c}$ \\
Risperidone & $75 \pm 8$ & $3 \pm 0.1$ & $7 \pm 1^{c}$ \\
Remoxipride & $>10,000$ & $275 \pm 180$ & $3690 \pm 360^{b}$ \\
Seroquel & $455 \pm 105$ & $160 \pm 15$ & - \\
Org 5222 & $5 \pm 0.1$ & $1 \pm 0.1$ & - \\
Haloperidol & $25 \pm 7$ & $1 \pm 0.04$ & $5 \pm 0.5^{b}$ \\
\hline
\end{tabular}

\footnotetext{
${ }^{a}$ The $\mathrm{K}_{\mathrm{i}} \pm \mathrm{SE}$ values for the dopamine receptor subtypes were determined as described in Materials and Methods. All compounds were tested in at least three independent experiments at each receptor subtype.

${ }^{b}$ Data from Van Tol et al. 1991.

'Data from Seeman and Van Tol 1993b.
}

from at least three separate experiments performed in duplicate or triplicate with at least 6 to 11 concentrations of drugs. The data were analyzed and $\mathrm{IC}_{50}$ values determined using either Allfit (De Lean et al. 1978) or Ligand (Munson and Rodbard 1980) software programs, and inhibition constants $\left(K_{\mathrm{i}}\right)$ were calculated utilizing the Cheng-Prusoff equation (Cheng and Prusoff 1973). The Hill coefficients of the antipsychotics for the various neuronal receptors were not significantly different from unity.

Olanzapine was synthesized in the Lilly Research Laboratories and the other antipsychotics were from the following sources: clozapine (Sandoz), risiperidone (Janssen), remoxipride (Astra), seroquel (Zeneca), Org 5222 (Organon), and haloperidol (Research Biochemicals, Inc., Natick, MA). The following radioligands were used for the binding studies: $\left[{ }^{3} \mathrm{H}\right]$ pirenzepine $(87.0$ $\mathrm{Ci} / \mathrm{mmol}),\left[{ }^{3} \mathrm{H}\right] \mathrm{n}$-methylscopolamine $\left(\left[{ }^{3} \mathrm{H}\right] \mathrm{NMS}, 79.5\right.$ $\mathrm{Ci} / \mathrm{mmol}),\left[{ }^{3} \mathrm{H}\right] 8-O H D P A T(142.9 \mathrm{Ci} / \mathrm{mmol}),\left[{ }^{3} \mathrm{H}\right] 5 \mathrm{HT}$ $(25.4 \mathrm{Ci} / \mathrm{mmol}),\left[{ }^{3} \mathrm{H}\right]$ ketanserin $(60 \mathrm{Ci} / \mathrm{mmol}),\left[{ }^{3} \mathrm{H}\right]-$ prazosin $(70 \mathrm{Ci} / \mathrm{mmol}),\left[{ }^{3} \mathrm{H}\right]$ rauwolscine $(70 \mathrm{Ci} / \mathrm{mmol})$, [ $\left.{ }^{3} \mathrm{H}\right]$ dihydroalprenolol $\left(\left[{ }^{3} \mathrm{H}\right] \mathrm{DHA}, 70 \mathrm{Ci} / \mathrm{mmol}\right),\left[{ }^{3} \mathrm{H}\right]-$ SCH23390 $(79 \mathrm{Ci} / \mathrm{mmol}),\left[{ }^{3} \mathrm{H}\right]$ raclopride $(60 \mathrm{Ci} / \mathrm{mmol})$, $\left[{ }^{3} \mathrm{H}\right]$ flunitrazepam $(60 \mathrm{Ci} / \mathrm{mmol}),\left[{ }^{3} \mathrm{H}\right]$ pyrilamine $(20$ $\mathrm{Ci} / \mathrm{mmol})$, and $\left[{ }^{3} \mathrm{H}\right]$ muscimol $(20 \mathrm{Ci} / \mathrm{mmol})$ were purchased from New England Nuclear Corp.; and $\left[{ }^{3} \mathrm{H}\right]$ mesulergine $(85 \mathrm{Ci} / \mathrm{mmol})$ and $\left[{ }^{3} \mathrm{H}\right] \mathrm{LY} 278584$ ( $80.5 \mathrm{Ci} / \mathrm{mmol}$ ) were supplied by Amersham Laboratories. All other chemicals used were reagent grade and were obtained from Sigma Chemical Company (St. Louis, MO).

\section{RESULTS}

Olanzapine had high affinity for dopamine receptor subtypes (Table 3, Fig. 1). Olanzapine had inhibition constants $\left(K_{\mathrm{i}}\right)$ of 31 and $11 \mathrm{nM}$ for $\mathrm{D}_{1}$ and $\mathrm{D}_{2}$ receptors in rat striatum, respectively. Moreover, olanzapine inhibited binding to human $\mathrm{D}_{4}$ receptors transfected into COS-7 cells with a $K_{\mathrm{i}}$ of $27 \mathrm{nM}$. Olanzapine had higher affinity than clozapine for $D_{1}$ and $D_{2}$ receptors, but clozapine had slightly higher affinity for $\mathrm{D}_{4}$ receptors (Table 3; Seeman and Van Tol 1993b; Van Tol et al. 1991). Haloperidol, risperidone, and Org 5222 had high affinity for $\mathrm{D}_{2}$ receptors and were considerably less potent on $\mathrm{D}_{1}$ receptors. In addition, haloperidol and risperidone had high affinity for $\mathrm{D}_{4}$ receptors (Seeman and Van Tol 1993b; Van Tol et al. 1991). Remoxipride and seroquel had relatively low affinity for $D_{1}$ and $D_{2}$

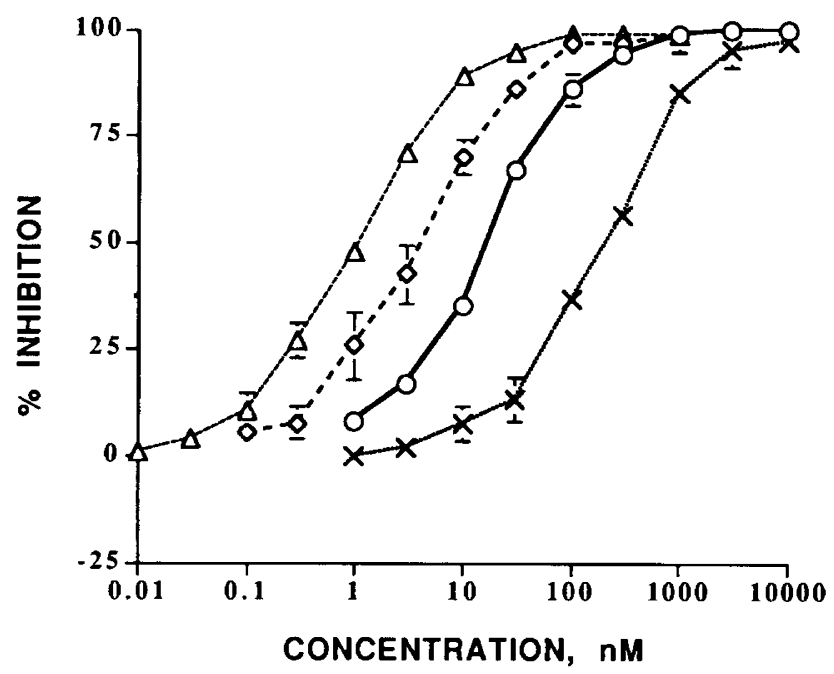

Figure 1. Inhibition of binding to dopamine $\mathrm{D}_{2}$ receptors by haloperidol, risperidone, olanzapine, and clozapine. The concentration-dependent inhibition of ${ }^{3} \mathrm{H}$-spiperone binding to dopamine $D_{2}$ receptors by haloperidol $(\triangle)$, risperidone $(\diamond)$ olanzapine $(O)$ and clozapine $(x)$ was determined in rat striatal membranes. Vertical lines represent $\pm 1 \mathrm{SE}$ and are absent when less than the size of the point. 
Table 4. Affinity Constants $\left(K_{\mathrm{i}}[\mathrm{nM}]\right)$ for Olanzapine, Clozapine, and Other Antipsychotic Compounds for Serotonin Receptor Subtypes ${ }^{a}$

\begin{tabular}{lcccccc}
\hline & \multicolumn{6}{c}{$\left.\boldsymbol{K}_{\mathbf{i}} \mathbf{( n M}\right)$} \\
\cline { 2 - 7 } Compound & $\mathbf{5} \mathbf{H T}_{\mathbf{1 A}}$ & $\mathbf{5} \mathbf{H T}_{\mathbf{1 B}}$ & $\mathbf{5 H T}_{\mathbf{1 D}}$ & $\mathbf{5 H T}_{\mathbf{2 A}}$ & $\mathbf{5 H T}_{\mathbf{2 C}}$ & $\mathbf{5 H T}_{\mathbf{3}}$ \\
\hline Olanzapine & $>1000$ & $1355 \pm 380$ & $800 \pm 190$ & $4 \pm 0.4$ & $11 \pm 1$ & $57 \pm 6$ \\
Clozapine & $770 \pm 220$ & $1200 \pm 170$ & $980 \pm 115$ & $\mathbf{1 2} \pm 3$ & $8 \pm 0.8$ & $69 \pm 8$ \\
Risperidone & $490 \pm 10$ & $1325 \pm 130$ & $100 \pm 11$ & $0.6 \pm 0.2$ & $26 \pm 5$ & $\mathrm{~N}^{b}$ \\
Remoxipride & $\mathrm{N}^{b}$ & $\mathrm{~N}^{b}$ & 6150 & $\mathrm{~N}^{b}$ & $\mathrm{~N}^{b}$ & $\mathrm{~N}^{b}$ \\
Seroquel & $2450 \pm 500$ & $5400 \pm 350$ & 6220 & $220 \pm 4$ & $615 \pm 110$ & $170 \pm 15$ \\
Org 5222 & $19 \pm 4$ & $68 \pm 4$ & 18 & $0.4 \pm 0.3$ & $0.2 \pm 0.05$ & 3000 \\
Haloperidol & $7930 \pm 500$ & $\mathrm{~N}^{b}$ & $6950 \pm 950$ & $78 \pm 22$ & 3085 & $>1000$ \\
\hline
\end{tabular}

\footnotetext{
${ }^{a}$ The $K_{\mathrm{i}}$ values $\pm \mathrm{SE}$ for the serotonin receptor subtypes were determined as described in Materials and Methods. All compounds were tested in duplicate in at least two or three (with SE) independent experiments at each receptor site.

${ }^{b} \mathrm{~N}=$ Inhibition of binding $<50 \%$ at $10,000-\mathrm{nM}$ concentration.
}

receptors (Table 3), and remoxipride had low affinity for $D_{4}$ receptors (Van Tol et al. 1991).

Olanzapine was a potent inhibitor of radioligand binding to $5 \mathrm{HT}_{2 \mathrm{~A}}$ and $5 \mathrm{HT}_{2} \mathrm{C}$ receptor subtypes with $K_{\mathrm{i}}$ values of 4 and $11 \mathrm{nM}$, respectively, and had moderate affinity for $5 \mathrm{HT}_{3}$ receptors (Table 4). Olanzapine had lower affinity for $5 \mathrm{HT}_{1 \mathrm{~A}}, 5 \mathrm{HT}_{1 \mathrm{~B}}$, and $5 \mathrm{HT}_{1 \mathrm{D}}$ receptor subtypes. Clozapine had a similar radioligand binding profile for $5 \mathrm{HT}$ receptor subtypes. Risperidone was a potent inhibitor of $\left[{ }^{3} \mathrm{H}\right]$ ketanserin binding to $5 \mathrm{HT}_{2} \mathrm{~A}$ receptors with a $K_{\mathrm{i}}$ value of $0.6 \mathrm{nM}$, had moderate affinity for $5 \mathrm{HT}_{2 \mathrm{C}}$ and $5 \mathrm{HT}_{1 \mathrm{D}}$ receptors, and low affinity for $5 \mathrm{HT}_{1 \mathrm{~A}}, 5 \mathrm{HT}_{1 \mathrm{~B}}$, and $5 \mathrm{HT}_{3}$ receptors. Org $5222 \mathrm{had}$ very high affinity for $5 \mathrm{HT}_{2 \mathrm{~A}}$ and $5 \mathrm{HT}_{2} \mathrm{C}$ receptors with $K_{\mathrm{i}}$ values less than $1 \mathrm{nM}$ and high affinity for $5 \mathrm{HT}_{1 \mathrm{~A}}$ and $5 \mathrm{HT}_{1 \mathrm{D}}$ receptors but did not have appreciable affinity for $5 \mathrm{HT}_{3}$ receptors. Seroquel had moderate affinity for $5 \mathrm{HT}_{2 \mathrm{~A}}$ and $5 \mathrm{HT}_{3}$ receptors and relatively low affinity for the other serotonin receptor subtypes. Haloperidol interacted with $5 \mathrm{HT}_{2 \mathrm{~A}}$ receptors with moderate affinity and had very low affinity for other serotonin receptor subtypes. On the other hand, remoxipride did not have appreciable affinity for any of the serotonin receptor subtypes examined.

Table 5. The $K_{\mathrm{i}}$ Values (nM) for Olanzapine, Clozapine, and Other Antipsychotic Compounds for Muscarinic Receptor Subtypes ${ }^{a}$

\begin{tabular}{|c|c|c|c|c|}
\hline \multirow[b]{2}{*}{ Compound } & \multicolumn{4}{|c|}{$K_{\mathrm{i}}(\mathrm{nM})$} \\
\hline & $\mathbf{m}_{1}$ & $\mathbf{m}_{2}$ & $\mathbf{m}_{3}$ & $\mathbf{m}_{4}$ \\
\hline \multicolumn{5}{|l|}{ Rat tissue } \\
\hline Olanzapine & $1.9 \pm 0.1$ & $18 \pm 5$ & $25 \pm 2$ & $13 \pm 2$ \\
\hline Clozapine & $1.9 \pm 0.4$ & $10 \pm 1$ & $14 \pm 1$ & $18 \pm 5$ \\
\hline Risperidone & $\mathrm{N}^{b}$ & $\overline{\mathrm{N}}^{b}$ & $\mathrm{~N}^{b}$ & $\bar{N}^{b}$ \\
\hline Remoxipride & $\mathrm{N}^{b}$ & $\mathrm{~N}^{b}$ & $\mathrm{~N}^{b}$ & $\mathrm{~N}^{b}$ \\
\hline Seroquel & $120 \pm 35$ & $630 \pm 230$ & $1320 \pm 80$ & $660 \pm 100$ \\
\hline Org 5222 & $\bar{N}^{b}$ & $\mathrm{~N}^{b}$ & $\mathrm{~N}^{b}$ & $\mathrm{~N}^{b}$ \\
\hline \multirow[t]{2}{*}{ Haloperidol } & $1475 \pm 300$ & $1200 \pm 180$ & $1600 \pm 305$ & $\mathrm{~N}^{b}$ \\
\hline & $\mathbf{m}_{1}$ & $\mathbf{m}_{3}$ & $\mathbf{m}_{4}$ & $\mathbf{m}_{5}$ \\
\hline \multicolumn{5}{|c|}{$\begin{array}{l}\text { Cell lines transfected } \\
\text { with muscarinic } \\
\text { receptors }\end{array}$} \\
\hline Olanzapine & $2.5 \pm 0.3$ & $13 \pm 0.8$ & $10 \pm 0.6$ & $6 \pm 0.8$ \\
\hline Clozapine & $1.4 \pm 0.3$ & $7 \pm 1$ & $6 \pm 0.5$ & $5 \pm 1.2$ \\
\hline Risperidone & $\overline{\mathrm{N}}^{b}$ & $\bar{N}^{b}$ & $\bar{N}^{b}$ & $\bar{N}^{b}$ \\
\hline Remoxipride & $\mathrm{N}^{b}$ & $\mathrm{~N}^{b}$ & $\mathrm{~N}^{b}$ & $\mathrm{~N}^{b}$ \\
\hline Seroquel & $135 \pm 30$ & $705 \pm 45$ & $225 \pm 40$ & $2990 \pm 670$ \\
\hline Org 5222 & $\bar{N}^{b}$ & $\overline{\mathbf{N}}^{b}$ & $\bar{N}^{b}$ & $\overline{\mathrm{N}}^{b}$ \\
\hline
\end{tabular}

${ }^{a}$ The $K_{\mathrm{i}} \pm \mathrm{SE}$ values $(\mathrm{nM})$ for the muscarinic receptor subtypes were determined using $[\mathrm{H}]$ pirenzepine binding to $m_{1}$ receptors in cerebral cortex, $\left.{ }^{3} \mathrm{H}\right]$ NMS binding to heart tissue for $m_{2}$ receptors, $\left[{ }^{3} \mathrm{H}\right] \mathrm{NMS}$ binding to submaxillary salivary glands for $\mathrm{m}_{3}$ receptors, and $\left[{ }^{3} \mathrm{H}\right] \mathrm{NMS}$ binding to striatum with dissociation for $\mathrm{m}_{4}$ receptors. Muscarinic receptor binding in $\mathrm{CHO}-\mathrm{K} 1$ cell lines was determined with $\left[{ }^{3} \mathrm{H}\right] \mathrm{NMS}$ binding to muscarinic receptors as described in Materials and Methods. All compounds were tested in at least three independent experiments at each receptor site.

${ }^{b} N=$ Inhibition of binding $<50 \%$ at $10,000-\mathrm{nM}$ concentration. 
Table 6. The $K_{\mathrm{i}}$ Values for Olanzapine, Clozapine, and Other Antipsychotic Compounds for Adrenergic,

Histaminergic, GABAergic, and

Benzodiazepine Receptors ${ }^{a}$

\begin{tabular}{lcrc}
\hline & \multicolumn{3}{c}{$\mathbf{K}_{\mathbf{i}}(\mathbf{n M})^{b}$} \\
\cline { 2 - 4 } Compound & \multicolumn{1}{c}{$\boldsymbol{\alpha}_{\mathbf{1}}$} & \multicolumn{1}{c}{$\boldsymbol{\alpha}_{\mathbf{2}}$} & \multicolumn{1}{c}{$\mathbf{H}_{\mathbf{1}}$} \\
\hline Olanzapine & $19 \pm 1$ & $230 \pm 40$ & $7 \pm 0.3$ \\
Clozapine & $7 \pm 4$ & $8 \pm 3$ & $6 \pm 2$ \\
Risperidone & $2 \pm 0.1$ & $3 \pm 0.7$ & $155 \pm 35$ \\
Remoxipride & $>10,000$ & $2900 \pm 125$ & $>10,000$ \\
Seroquel & $7 \pm 0.2$ & $87 \pm 4$ & $11 \pm 12$ \\
Org 5222 & $1 \pm 0.3$ & $4 \pm 0.7$ & $2 \pm 2.0$ \\
Haloperidol & $46 \pm 6$ & $360 \pm 100$ & $3630 \pm 85$ \\
\hline
\end{tabular}

a The $K_{\mathrm{i}}$ values $+\mathrm{SE}$ for $\alpha_{1}$-adrenergic, $\alpha_{2}$-adrenergic, histamine $\mathrm{H}_{1}, \beta$-adrenergic, GABA $A_{A}$, and benzodiazepine receptors were determined in rat tissues as described in Materials and Methods. All compounds were tested in at least 3 independent experiments at each receptor site.

${ }^{b}$ The compounds did not inhibit $50 \%$ of the binding to $\mathrm{GABA}_{\mathrm{A}}$, $\beta$-adrenergic, and benzodiazepine receptors at $10-\mu \mathrm{M}$ concentration.

Binding of radioligands to muscarinic receptor subtypes in rat tissue and in CHO-K1 cell lines transfected with muscarinic receptor subtypes was potently inhibited by olanzapine (Table 5). Olanzapine and clozapine had highest affinity for $m_{1}$ receptors among all the neuronal receptors examined with $K_{\mathrm{i}}$ values in cell lines of 2.5 and $1.4 \mathrm{nM}$, respectively, and in rat cortex the $K_{\mathrm{i}}$ value was $1.9 \mathrm{nM}$ for both compounds. On the other hand, risperidone, remoxipride, seroquel, Org 5222 , and haloperidol had moderate to low affinity for muscarinic receptors.

The binding to $\alpha_{1}$ - and $\alpha_{2}$-adrenergic receptors was inhibited by olanzapine with $K_{\mathrm{i}}$ values of 19 and 230 $\mathrm{nM}$, respectively; in contrast, clozapine had higher affinity for $\alpha_{1}$-adrenergic receptors and in particular for

Table 7. Inhibition of Radioligand Binding by Olanzapine to Human Neuronal Receptors ${ }^{a}$

\begin{tabular}{lr}
\hline \multicolumn{1}{c}{ Receptor } & IC $_{\mathbf{5 0}}$ (nM) \\
\hline Dopamine $\mathrm{D}_{1}$ & $25 \pm 4$ \\
Dopamine $\mathrm{D}_{2}$ & $10 \pm 2$ \\
$\mathrm{HT}_{2 \mathrm{~A}}$ & $7 \pm 2$ \\
$5 \mathrm{HT}_{2 \mathrm{C}}$ & $71 \pm 8$ \\
Muscarinic m 1 & $2 \pm 0.1$ \\
$\alpha_{1}$-adrenergic & $70 \pm 14$ \\
$\alpha_{2}$-adrenergic & $280 \pm 20$ \\
$\beta_{\text {-adrenergic }}$ & $>10,000$ \\
GABA & $>10,000$ \\
Benzodiazepine & $>10,000$ \\
\hline
\end{tabular}

${ }^{a}$ The affinity of olanzapine for $D_{1}$ and $D_{2}$ receptors was determined in human corpus striatum. The inhibition of binding by olanzapine was determined in membranes from human frontal cortex for $5 \mathrm{HT}_{2 \mathrm{~A}}, 5 \mathrm{HT}_{2 \mathrm{C}}, \mathrm{m}_{1}, \alpha_{1}$-adrenergic, $\alpha_{2}$-adrenergic, $\beta$-adrenergic, $\mathrm{GABA}_{\mathrm{A}}$, and benzodiazepine receptors as described in Materials and Methods. The $\mathrm{IC}_{50}$ values $\pm \mathrm{SE}$ are the mean of at least three independent experiments at each receptor site.

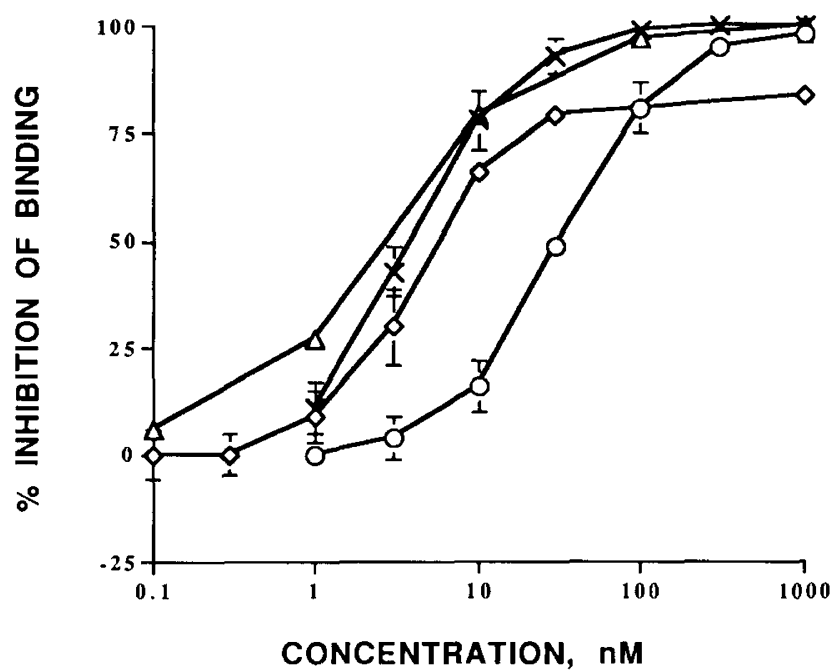

Figure 2. Inhibition of binding to various receptors from human tissue by olanzapine. The concentration-dependent inhibition of binding to dopamine $D_{1}(O)$ and dopamine $D_{2}(x)$ receptors by olanzapine was determined in human striatum. The inhibition of binding to $5 \mathrm{HT}_{2 \mathrm{~A}}(\diamond)$ and muscarinic $\mathrm{M}_{1}(\triangle)$ receptors by olanzapine was determined in human frontal cortex. Vertical lines represent $\pm 1 \mathrm{SE}$ and are absent when less than the size of the point.

$\alpha_{2}$-adrenergic receptors (Table 6). Risperidone, Org 5222 , and seroquel also had high affinity for $\alpha_{1}$-adrenergic and $\alpha_{2}$-adrenergic receptors. None of the antipsychotic compounds had affinity for $\beta$-adrenergic receptors (Table 6).

Olanzapine, clozapine, seroquel, and Org $5222 \mathrm{had}$ high affinity for histamine $\mathrm{H}_{1}$ receptors (Table 6). None of the compounds evaluated had appreciable affinity for $\mathrm{GABA}_{\mathrm{A}}$ or benzodiazepine receptors.

The inhibition of radioligand binding to receptors in human brain tissue was examined (Table 7, Figure 2). Olanzapine had high affinity for dopamine $D_{1}$ and $\mathrm{D}_{2}$ receptors in human striatal tissue and for $5 \mathrm{HT}_{2} \mathrm{~A}$, $5 \mathrm{HT}_{2 \mathrm{C}}, \mathrm{m}_{1}$, and $\alpha_{1}$-adrenergic receptors in human frontal cortex. We were unable to determine specific binding of $\left[{ }^{3} \mathrm{H}\right]$ pyrilamine to histamine $\mathrm{H}_{1}$ receptors in human frontal cortex.

\section{DISCUSSION}

Olanzapine exhibited high affinity for dopamine $\mathrm{D}_{1}$, $\mathrm{D}_{2}, \mathrm{D}_{4}, 5 \mathrm{HT}_{2 \mathrm{~A}}, 5 \mathrm{HT}_{2} \mathrm{C}, 5 \mathrm{HT}_{3}, \alpha_{1}$-adrenergic, histamine $\mathrm{H}_{1}$, and five subtypes of muscarinic receptors in animal tissues and cell lines transfected with neuronal receptors. The receptor binding profile of olanzapine was compared to the atypical antipsychotic clozapine, the widely used typical antipsychotic haloperidol and the new antipsychotics risperidone (Leysen et al. 1988; 
Roose et al. 1988), remoxipride (Lewander et al. 1990), seroquel (Migler et al. 1993; Saller and Salama 1993), and Org 5222 (Siten and Vrijmoed-de Vries 1992). Only olanzapine had a broad radioreceptor binding profile that mirrored the profile of the prototype clozapine. For example, haloperidol had high affinity for dopamine $D_{2}$ and $D_{4}$ receptors, moderate affinity for dopamine $D_{1}$ and $\alpha_{1}$-adrenergic receptors, and relatively low affinity for the other receptors examined. Risperidone had high affinity for $5 \mathrm{HT}_{2 \mathrm{~A}}$, dopamine $\mathrm{D}_{1}, \mathrm{D}_{2}, \mathrm{D}_{4}, \alpha_{1^{-}}$ adrenergic, $\alpha_{2}$-adrenergic receptors $\left(K_{\mathrm{i}}<100 \mathrm{nM}\right)$, but had moderate affinity $\left(K_{\mathrm{i}}\right.$ between 100 and $\left.1000 \mathrm{nM}\right)$ for histamine $\mathrm{H}_{1}$ receptors and was devoid of activity at muscarinic receptors. Seroquel had high affinity for $\alpha_{1^{-}}, \alpha_{2}$-adrenergic and histamine $\mathrm{H}_{1}$ receptors and moderate affinity for dopamine $\mathrm{D}_{1}, \mathrm{D}_{2}, 5 \mathrm{HT}_{2 \mathrm{~A}}, 5 \mathrm{HT}_{3}$, and $m_{1}$ receptors. Remoxipride had moderate affinity for dopamine $\mathrm{D}_{2}$ receptors but had low affinity for the other receptors examined. Org 5222 had high affinity for the $5 \mathrm{HT}_{1}$ and $5 \mathrm{HT}_{2}$ subtypes, dopamine $\mathrm{D}_{1}, \mathrm{D}_{2}, \boldsymbol{\alpha}_{1^{-}}$ adrenergic, $\alpha_{2}$-adrenergic, and histamine $\mathrm{H}_{1}$ receptors, but had low affinity for the muscarinic receptor subtypes. Thus, high affinity for muscarinic receptors subtypes is unique for olanzapine and clozapine among the antipsychotics tested. Interestingly, all the antipsychotic compounds tested, with the exception of remoxipride, had high affinity for the $\alpha_{1}$-adrenergic receptor and a number had high affinity for the histamine $\mathrm{H}_{1}$ receptor. In general, the binding results presented here for antipsychotic compounds are in agreement with those of previous studies (Bolden et al. 1992; Leysen et al. 1988; Meltzer et al. 1989; Saller and Salama 1993; Seeman et al. 1976).

The blockade of dopamine $\mathrm{D}_{2}$ receptors in the mesolimbic area has been hypothesized to play an important role in the efficacy of antipsychotic drugs (Creese et al. 1976; Seeman et al. 1976). However, interaction with other dopamine receptor subtypes may be critical to produce the atypical profile of clozapine. For example, clozapine was a potent inhibitor of the binding of radioligands to dopamine $\mathrm{D}_{1}, \mathrm{D}_{2}$, and particularly $\mathrm{D}_{4}$ receptors. Olanzapine also had high affinity for dopamine $D_{1}, D_{2}$, and $D_{4}$ receptors, although olanzapine had higher affinity for $D_{1}$ and $D_{2}$ receptors and clozapine was slightly more potent at $\mathrm{D}_{4}$ receptors. High potency at $D_{1}$ receptors relative to $D_{2}$ receptors has been suggested to reduce EPS liability (Andersen et al. 1986). Dopamine $D_{4}$ receptors have been implicated in schizophrenia by the finding that the number of $\mathrm{D}_{4}$ receptors are elevated in schizophrenic patients (Seeman et al. 1993), and clozapine has about 10 times higher affinity for $\mathrm{D}_{4}$ than $\mathrm{D}_{2}$ receptors (Van Tol et al. 1991).

The atypical nature of clozapine may also involve interaction with nondopaminergic receptors. For example, high affinity for $5 \mathrm{HT}_{2 \mathrm{~A}}$ receptors relative to $\mathrm{D}_{2}$ receptors has been postulated to be involved in low EPS potential (Altar et al. 1986; Meltzer et al. 1989; Rasmussen and Aghajanian 1988). In this regard olanzapine, as well as clozapine, was more potent in inhibiting binding of radioligands to $5 \mathrm{HT}_{2 \mathrm{~A}}$ than dopamine $\mathrm{D}_{2}$ receptors. In addition to $5 \mathrm{HT}_{2 \mathrm{~A}}$ receptors, olanzapine and clozapine (Canton et al. 1990; Roth et al. 1992) also have high affinity for $5 \mathrm{HT}_{2} \mathrm{C}$ receptors. Clozapine has high affinity for cloned $5 \mathrm{HT}_{6}$ and $5 \mathrm{HT}_{7}$ receptor subtypes, whereas olanzapine only has high affinity for $5 \mathrm{HT}_{6}$ receptors (Roth et al. 1994). Moreover, olanzapine and clozapine have moderate affinity for $5 \mathrm{HT}_{3}$ receptors, and $5 \mathrm{HT}_{3}$ antagonists have been hypothesized to have antipsychotic potential through interaction with the dopamine system (Costall et al. 1987; Rasmussen et al. 1991). Thus, olanzapine and clozapine have high affinity for a number of the $5 \mathrm{HT}$ receptor subtypes, and this, along with interaction with other receptors, may be a key factor in their atypical nature.

Only olanzapine and clozapine among the compounds tested have high affinity for the $m_{1}$ receptor subtype, and it has been proposed that $m_{1}$ selectivity may contribute to the atypical profile of antipsychotics (Bolden et al. 1992). In addition, interaction with muscarinic receptors reduce the cataleptogenic response of antipsychotic compounds (Jenner and Marsden 1983). Olanzapine, clozapine, and antipsychotics in general have a high affinity for $\alpha_{1}$-adrenergic receptors that may contribute to their antipsychotic activity (Cohen and Lipinski 1986).

Although the overall binding profile of olanzapine is quite comparable to that of clozapine, the radioreceptor binding affinity of olanzapine for $\alpha$-adrenergic receptors is significantly different from that of clozapine. The affinity of olanzapine for $\alpha_{1}$-adrenergic receptors was about one-half of the dopamine $\mathrm{D}_{2}$ affinity, while the affinity of clozapine for $\alpha_{1}$-adrenergic receptors was about 18 times higher than the dopamine $\mathrm{D}_{2}$ affinity. In addition, the affinity of clozapine for $\alpha_{2}$-adrenergic receptors was 28 times higher than that of olanzapine. The decreased affinity of olanzapine for $\alpha$-adrenergic receptors suggests that this compound may be less likely to produce sedation and hypotension, which are side effects closely related to the $\alpha$-adrenergic blockade produced by certain antipsychotics (Peroutka and Snyder 1980).

The binding profile of olanzapine in human brain tissue was consistent with results obtained in animal tissue. In human tissue olanzapine had high affinity for dopamine $\mathrm{D}_{1}, \mathrm{D}_{2}, 5 \mathrm{HT}_{2 \mathrm{~A}}, 5 \mathrm{HT}_{2 \mathrm{C}}, \mathrm{m}_{1}$, and $\alpha_{1}$-adrenergic receptors, as found in rat tissues. Olanzapine had very low affinity for $\beta$-adrenergic, benzodiazepine, and $\mathrm{GABA}_{\mathrm{A}}$ receptors in both human and rat tissues.

The similar broad radioreceptor binding profiles of olanzapine and clozapine in rat and human tissues suggest that olanzapine would also have a broad pharmaco- 
logical profile in vivo. In fact, olanzapine has potent antidopaminergic activity in vivo as demonstrated by the blockade of apomorphine-induced climbing behavior in mice (Moore et al. 1992) and the pergolide-induced increases in serum corticosterone in rats (Fuller and Snoddy 1992). In neurochemical studies, olanzapine increased the levels of dopamine metabolites in the striatum and nucleus accumbens and lowered the levels of striatal acetylcholine in rats, consistent with antagonism of $D_{2}$ receptors (Hemrick-Luecke et al. 1993). Olanzapine not only was a potent dopamine antagonist in vivo but also had activity in vivo at other neuronal receptors. The antiserotonergic and anticholinergic activity of olanzapine was demonstrated by potent blockade of 5-hydroxytrytophan-induced head twitches and oxotremorine-induced tremors in mice, respectively (Moore et al. 1992). Further, olanzapine blocked quipazineinduced elevation of serum corticosterone in rats, indicative of $5 \mathrm{HT}_{2}$ antagonism (Fuller and Snoddy 1992).

Olanzapine is also active in animal models that have been used to predict antipsychotic and anxiolytic activity. For example, olanzapine was active in conditioned avoidance responding (Moore et al. 1992) that has been used as test for predicting antipsychotic activity (Arnt 1982). Moreover, olanzapine produced catalepsy only at doses fourfold higher than those required to block conditioned avoidance responding (Moore et al. 1992). The induction of catalepsy by antipsychotic compounds has been associated with EPS production in man (Worms et al. 1983). Furthermore, olanzapine substituted for the discriminative effects of clozapine in rats and had activity similar to clozapine in a conflict schedule (Moore et al. 1994) despite no appreciable affinity for benzodiazepine receptors. In addition, electrophysiological studies demonstrated that chronic olanzapine treatment selectively reduced the number of spontaneously firing mesolimbic dopamine cells (A10) without altering the number of spontaneously firing nigrostriatal dopamine (A9) cells (Stockton and Rasmussen 1996). Clozapine, but not haloperidol, displayed a similar selectivity for decreasing A10 dopamine cell activity (Chiodo and Bunney 1983; White and Wang 1983). Therefore, olanzapine has a broad pharmacological profile in animals similar to that clozapine and consistent with that of an atypical antipsychotic. Indeed, in preliminary clinical trails olanzapine has been demonstrated to have efficacy in reducing both the positive and negative symptoms of schizophrenia, coupled with a favorable adverse event profile, including a low level of EPS and minimal elevation of prolactin levels (Beasley et al. 1996).

\section{ACKNOWLEDGMENTS}

The authors acknowledge the generous gift of compounds from Astra, Janssen, Organon, Zeneca, and Sandoz compa- nies. The authors acknowledge helpful comments on the manuscript from Drs. Harlan E. Shannon and Kurt Rasmussen and from Ms. Marsha Stockton.

\section{REFERENCES}

Altar CA, Wasley AM, Neale RF, Stone GA (1986): Typical and atypical antipsychotic occupancy of $D_{2}$ and $S_{2}$ receptors: An autoradiographic analysis in rat brain. Brain Res Bull 16:517-525

Andersen PH, Nielsen EB, Gronvald FC, Braestrup C (1986): Some atypical neuroleptics inhibit $\left[{ }^{3} \mathrm{H}\right] \mathrm{SC} \mathrm{C} 23390$ binding in vivo. Eur J Pharmacol 120:143-144

Arnt J (1982): Pharmacological specificity of conditioned avoidance response inhibition in rats: Inhibition by neuroleptics and correlation to dopamine receptor blockade. Acta Pharmacol Toxicol 51:321-329

Beasley CM, Tollefson GD, Tran P, Satterlee W, Sanger T, Holman S, The Olanzapine HGAD Study Group (1996): Olanzapine versus placebo and haloperidol: Acute phase results of the North American double blind olanzapine trial. Neuropsychopharmacology 14:111-123

Bolden C, Cusack B, Richelson E (1992): Antagonism by antimuscarinic and neuroleptic compounds at the five cloned human muscarinic cholinergic receptors expressed in Chinese hamster ovary cells. J Pharmacol Exp Ther 260:576-580

Boyajian CL, Leslie FM (1987): Pharmacological evidence for alpha-2 adrenoceptor heterogeneity: Differential properties of $\left[{ }^{3} \mathrm{H}\right]$ rauwolscine and $\left[{ }^{4} \mathrm{H}\right]$ idazoxan in rat brain. J Pharmacol Exp Ther 241:1092-1098

Braestrup C, Squires RF (1977): Specific benzodiazepine receptor in rat brain characterized by high affinity $\left[{ }^{3} \mathrm{H}\right]$ diazepam binding. Proc Natl Acad Sci USA 74:3805-3809

Byland DB, Snyder SH (1976): Beta adrenergic receptor binding in membrane preparations from mammalian brain. Mol Pharmacol 12:568-580

Canton H, Verriele L, Colpaert FC (1990): Binding of typical and atypical antipsychotics to $5-\mathrm{HT}_{1} \mathrm{C}$ and $5 \mathrm{HT}_{2}$ sites: Clozapine potently interacts with $5 \mathrm{HT}_{1 \mathrm{C}}$ sites. Eur J Pharmacol 191:93-96

Casey DE (1989): Clozapine: Neuroleptic-induced EPS and tardive dyskinesia. Psychopharmacology 99:S47-S53

Chakrabarti JK, Horsman L, Hotten TM, Pullar IA, Tupper DE, Wright FC (1980): 4-Piperazinyl-10H-thieno[2,3-b] $[1,5]$ benzodiazepines as potential neuroleptics. J Med Chem 23:878-884

Cheng YC, Prusoff WH (1973): Relationship between the inhibition constant $\left(K_{\mathrm{i}}\right)$ and the concentration of inhibitor which causes 50 percent inhibition $\left(I C_{50}\right)$ of an enzymatic reaction. Biochem Pharmacol 22:3090-3108

Chiodo LA, Bunney BS (1983): Typical and atypical neuroleptics: Differential effects of chronic administration on the activity of $A 9$ and $A 10$ midbrain dopaminergic neurons. J Neurosci 3:1607-1619

Claghorn J, Honigfeld G, Abuzzahab FS, Wang R, Steinbook R, Tuason V, Klerman G (1987): The risks and benefits of olanzapine versus chlorpromazine. J Clin Psychopharm 7:377-384

Cohen BM, Lipinski JF (1986): In vivo potencies of antipsychotic drugs in blocking alpha 1 noradrenergic and dopa- 
mine $D_{2}$ receptors: Implications for drug mechanism of action. Life Sci 39:2571-2580

Costall B, Domeney AM, Naylor RJ, Tyers MB (1987): Effects of the $5 \mathrm{HT}_{3}$ receptor antagonist GR38032F, on raised dopaminergic activity in the mesolimbic system of the rat and marmoset brain. Br J Pharmacol 92:881-894

Creese I, Burt DR, Snyder SH (1976): Dopamine receptor binding predicts clinical and pharmacological potencies of antischizophrenic drugs. Science 192:481-483

Davis JM, Casper R (1977): Antipsychotic drugs: Clinical pharmacology and therapeutic use. Drugs 14:260-282

De Lean A, Munson P, Rodbard D (1978): Simultaneous analysis of families of sigmoidal curves: Application to bioassay radioligand assay and physiological dose-response curves. Am J Physiol 234:E97-E102

Dorje F, Wess J, Lambrecht G, Tacke R, Mutschler E, Brann MR (1991): Antagonist binding profiles of five cloned muscarinic receptor subtypes. J Pharmacol Exp Ther 256:727-733

Farde L, Wiesel FA, Nordstrom A-L, Sedvall G (1989): D1and $D_{2}$-dopamine receptor occupancy during treatment with conventional and atypical neuroleptics. Psychopharmacology 99:S28-S31

Fuller RW, Snoddy HD (1992): Neuroendocrine evidence for antagonism of serotonin and dopamine receptors by olanzapine, an antipsychotic drug candidate. Res Comm Chem Path Pharmacol 77:87-93

Greengrass P, Bremner R (1979): Binding characteristics of ${ }^{3} \mathrm{H}$-prazosin to rat brain $\alpha$-adrenergic receptors. Eur $\mathbf{J}$ Pharmacol 55:323-326

Hall H, Kolder C, Gawell L, Farde L, Sedvall G (1988): Raclopride, a new selective ligand for the dopamine- $\mathrm{D}_{2}$ receptor. Prog Neuro-Psychopharmacol Biol Psychiatry 12:559-568

Hemrick-Luecke SK, Bymaster FP, Falcone JF, Moore NA, Tye NC, Fuller RW (1993): Effect of olanzapine on rat brain receptor binding, acetylcholine levels and monoamine turnover. Twenty-third Annual Society for Neuroscience Meeting, Washington, DC, pp 382, 158.9

Jenner P, Marsden CD (1983): Neuroleptics and tardive dyskinesia. In Coyle JT, Enna SJ (eds), Neuroleptics: Neurochemical, Behavioral, and Clinical Perspectives, New York, Raven, pp 223-253

Kane JM, Honigfeld G, Singer J, Meltzer H, The Clozaril Collaborative Study Group (1988): Clozapine for the treatment-resistant schizophrenic. Arch Gen Psychiatry 45:789-796

Krupp P, Barnes P (1992): Clozapine-associated agranulocytosis: Risk and aetiology. Br J Psychiatry 160(Suppl 17): 38-40

Lazareno S, Buckley NJ, Roberts FF (1990): Characterization of muscarinic $\mathrm{M}_{4}$ binding sites in rabbit lung, chicken heart, and NG108-15 cells. Mol Pharmacol 38:805-815

Lewander T, Westerbergh SE, Morrison D (1990): Clinical profile of remoxipride-A combined analysis of a comparative double-blind multi-centre trial programme. Acta Psychiatr Scand 82(Suppl 358):92-98

Leysen JE, Gommeren W, Eens A, de Chaffoy de Courcelles D, Stoof JC, Janssen PAJ (1988): Biochemical profiles of resperidone, a new antipsychotic. J Pharmacol Exp Ther 247:661-670
Meltzer HY, Matsubara S, Lee J-C (1989): Classification of typical and atypical antipsychotic drugs on the basis of dopamine D-1, D-2 and serotonin $2 \mathrm{pK}_{\mathrm{i}}$ values. J Pharmacol Exp Ther 251:238-246

Migler BA, Warawa EJ, Malick JB (1993): Seroquel: Behavioral effects in conventional and novel tests for atypical antipsychotic drug. Psychopharmacology 112:299-307

Miller RJ, Hiley CR (1974): Anti-muscarinic properties of neuroleptics and drug-induced parkinsonism. Nature (Lond) 248:596-597

Moore NA, Tye NC, Axton MS, Risius FC (1992): The behavioral pharmacology of olanzapine a novel "atypical" antipsychotic agent. J Pharmacol Exp Ther 262:545-551

Moore NA, Calligara DO, Wong DT, Bymaster FP, Tye NC (1993): The pharmacology of olanzapine and other new antipsychotic agents. Curr Opin Invest Drugs 2:281-293

Moore NA, Rees G, Sanger G, Tye NC (1994): Effect of olanzapine and other antipsychotic agents on responding maintained by a conflict schedule. Behav Pharmacol 5: 196-202

Munson PJ, Rodbard JD (1980): Ligand: A versatile computerized approach for characterization of ligand-binding systems. Anal Biochem 107:220-239

Peroutka SJ, Snyder SH (1980): Relationship of neuroleptic drug effects at brain dopamine, serotonin, $\alpha$-adrenergic, and histamine receptors to clinical potency. Am J Psychiatry 137:1518-1522

Potter LT, Ferrendelli CA, Hanchett HE (1988): Two affinity states of $\mathrm{M}_{1}$ muscarine receptors. Cell Molec Neurobiol 8:181-192

Rasmussen K, Aghajanian GK (1988): Potency of antipsychotics in reversing the effects of a hallucinogenic drug on locus coeruleus neurons correlates with $5 \mathrm{HT}_{2}$ binding affinity. Neuropsychopharmacology 1:101-107

Rasmussen K, Stockton ME, Czachura JF (1991): The $5 \mathrm{HT}_{3}$ receptor antagonist zatosetron decreases the number of spontaneously active A10 dopamine neurons. Eur J Pharmacol 205:113-116

Roose K, Gelders Y, Heylen S (1988): Risperidone (R 64766 ) in psychotic patients a first clinical therapeutic exploration. Acta Psychiatr Belg 88:233-241

Roth BL, Ciaranello RD, Meltzer HY (1992): Binding of typical and atypical antipsychotics agents to transiently expressed $5 \mathrm{HT}_{1 \mathrm{C}}$ receptors. J Pharmacol Exp Ther 260: 1361-1365

Roth BL, Craigo SC, Choudhary MS, Uluer A, Monsma FJ Jr, Shen Y, Meltzer HY, Sibley DR (1994): Binding of typical and atypical antipsychotics agents to 5-hydroxytryptamine-6 and 5-hydroxytryptamine-7 receptors. J Pharmacol Exp Ther 268:1403-1410

Saller CF, Salama AI (1993): Seroquel: Biochemical profile of a potential atypical antipsychotic. Psychopharmacology 112:185-292

Seeman P, Van Tol HHM (1993a): Dopamine $\mathrm{D}_{4}$ receptors bind (+)-aporphines, suggesting neuroleptic role, Sulpiride not stereoselective. Eur J Pharmacol 233:173-174

Seeman P, Van Tol HHM (1993b): Dopamine receptor pharmacology. Curr Opin Neurol Neurosurg 6:602-608

Seeman P, Lee T, Chang-Wong M, Wong K (1976): Antipsychotic drug doses and neuroleptic/dopamine receptors. Nature (Lond) 261:717-718 
Seeman P, Woodruff GN, Poat JA (1979): Similar binding of ${ }^{3} \mathrm{H}$-ADTN and ${ }^{3} \mathrm{H}$-apomorphine to calf brain dopamine receptors. Eur J Pharmacol 55:137-142

Seeman P, Guan H, Van Tol HHM (1993): Dopamine $D_{4}$ receptors elevated in schizophrenia. Nature (Lond) 365 : 441-445

Siten JMA, Vrijmoed-de Vries MC (1992): Org 5222 Preliminary clinical results. In Meltzer HY (ed), Novel antipsychotic drugs, New York, Raven Press, pp 145-154

Stockton ME, Rasmussen K (1996): Electrophysiological effects of olanzapine, a novel atypical antipsychotic, on A9 and A10 dopamine neurons. Neuropsychopharmacology 14:97-104

Tarsey D (1983): Neuroleptic-induced extrapyramidal reactions: Classification, description and diagnosis. Clin Neuropharmacol 6:S9-S26

Tran VT, Chang RSL, Snyder SH (1978): Histamine $\mathrm{H}_{1}$ receptor identified in mammalian brain membranes with $\left[{ }^{3} \mathrm{H}\right]$ mepyramine. Proc Natl Acad Sci USA 75:6290-6294

Van Tol HHM, Bunzow JR, Guan H-C, Sunahara RK, Seeman P, Niznik HB, Civelli O (1991): Cloning the gene for a human dopamine $D_{4}$ receptor with high affinity for the antipsychotic clozapine. Nature (Lond) 350:610-614
Waelbroeck M, Tastenoy M, Camus J, Christophe J (1990): Binding of selective antagonists to four muscarinic receptors $\left(\mathrm{M}_{1}\right.$ to $\left.\mathrm{M}_{4}\right)$ in rat forebrain. Mol Pharmacol 38: 267-273

White FJ, Wang RY (1983): Differential effects of classical and atypical antipsychotic drugs on A9 and A10 dopamine neurons. Science 221:1054-1057

Williams M, Risley EA (1979): Characterization of the binding of $\left[{ }^{3} \mathrm{H}\right]$ muscimol, a potent gamma-aminobutyric acid agonist, to rat brain synaptosomal membranes using filtration assay. J Neurochem 32:713-718

Wong DT, Threlkeld PG, Robertson DW (1991): Affinities of fluoxetine, it enantiomers and other inhibitors of serotonin uptake for subtypes of serotonin receptors. Neuropsychopharmacology 5:43-47

Wong DT, Moore NA, Calligaro DO, Bymaster FP, Seeman $P$ (1993): The preclinical pharmacology of olanzapine a novel antipsychotic. Ninth World Congress of Psychiatry, Rio de Janeiro, Brazil

Worms P, Broekkamp CLE, Lloyd K (1983): Behavioral effects of neuroleptics. In Coyle JT, Enna SJ (eds), Neuroleptics: Neurochemical, Behavioral, and Clinical Perspectives, New York, Raven, pp 93-117 